\title{
Special Feature \\ Emberley on Hot Button Politics in Canada's \\ Universities: A Critique
}

\section{A. SCOTT CARSON \\ Wilfrid Laurier University}

\section{ABSTRACT}

In his recent book, Zero Tolerance: Hot Button Politics in Canada's Universities (1996), Richard Emberley attacks the government, business community, university administrators, magazine publishers and academics for their complicity in pushing Canadian universities to the point of ruin. His accusation is that academe is pressed to achieve so many social, political and economic objectives that it risks not being successful in any of them. He provides a number of recommendations for restructuring higher education and these are presented in the context of a very rich conception of what a university should be. This paper examines Emberley's account of universities and the "scholarly culture" which has developed since the 13th century. It is argued that Emberley has an overly narrow view of the role of a university and one that is based on certain mistaken presumptions about what constitutes value in education.

\section{RÉSUMÉ}

Dans son nouveau livre, Zero Tolerance: Hot Button Politics in Canada's Universities (1996), Richard Emberley attaque le gouvernement, la communauté des affaires, les administrateurs des universités, les éditeurs de magazines, et les professeurs pour leur complicité dans l'effondrement 
des universités canadiennes. Le monde académique serait chargé de tant d'objectifs sociaux, politiques, et économiques qu'il risque de n'atteindre aucun d'entre eux. L'auteur recommande plusieurs réformes du système universitaire, au vu du riche contexte que devrait être une université. La présent article examine l'histoire des universités et la culture académique depuis son début au $13 \mathrm{e}$ siècle à partir des travaux d'Emberley. La perspective d'Emberley vis-à-vis du rôle des universités s'avère trop étroite et de plus, fondée sur des préjugés quant à ce qui devrait constituer la contribution de l'éducation au bien publique.

\section{CANADIAN UNIVERSITIES IN CRISIS}

For decades academics have been predicting the demise of the university. One recent disaster forecast is Peter Emberley's (1996) Zero Tolerance: Hot Button Politics in Canada's Universities. Emberley's starting point is with the arresting claim that Canadian universities are "under siege"(p. 1). He invites us to recall, for instance, the Fabrikant murders at Concordia, the shooting of women students at the École Polytechnique, allegations of systemic racism and sexism at UBC, strike votes and expressions of non-confidence in the president at Mount Allison, government funding cut-backs, high profile cases of scholars falsifying research data and much more. He laments that universities are in a state of crisis, caught between two extreme forces: the "corporate right" and the "cultural left". Each pushes the "hot buttons" of fabricated issues, and then offers "quick fix" solutions. These bandage-style remedies cannot work because they run counter to the traditions of academe and the "scholarly culture" which have developed since the Middle Ages. In consequence, "cracks are appearing all over the academic landscape" (p. 9), "testy relations have formed between universities and provincial governments"(p. 9), [P] arents are confused and angry" (p. 9), "professors are burning out"(p. 9), "support staff are stretched to the limit"(p. 9), "students are beside themselves"(p. 9), and the "general mood is discouraging" (p. 9). The university is itself "on the verge of financial, spiritual and political collapse" (p. 1). Indeed, Emberley asks, "can we today doubt, in light of the tumult in Canada's universities, that we are in the midst of anything less than a revolution - one that will forever change these institutions?" (p. 11). More, he says, "we are 
witnessing in this country overall a colossal breakdown of moral order in civil society. The university, with its openness to unconventionalism, is the primary site for this breakdown" (p. 237).

Emberley identifies a wide range of crimes against the university and berates virtually every educational constituency for complicity. But Professor Emberley has a solution and many recommendations which, if implemented, would constitute a major policy shift in Canadian higher education. Fundamental to his approach is detaching the university from the social and economic mandates which are being imposed upon it and returning to the historic ideals of scholarly contemplation and dialogue.

Emberley is not alone in his frustrations. Throughout the 1990s the already extensive literature on the challenges facing academe has grown further. For instance, D. D'Souza (1992) in Illiberal Education: The Politics of Race and Sex on Campus provided a compelling account of how race and gender policies at universities such as Berkeley, Stanford, Duke, Howard, Michigan and Harvard actually harmed those whom they were intended to help, and made liberal education a casualty in the process. These themes were picked up in edited collections such as The Imperiled Academy by Howard Dickman (1993) and in J. Arthur and A. Shapiro (1995) Campus Wars: Multiculturalism and the Politics of Difference. Similar matters were discussed in relation to academic freedom in L. Menand (Ed.) (1996), The Future of Academic Freedom. A lively and provocative Canadian account was provided by D. Bercuson, R. Bothwell and J. Granatstein (1997), Petrified Campus: The Crisis in Canada's Universities. As does Emberley, the latter also addressed issues such as university financing, tenure and the rising prominence of administrative functions such as strategic planning. J. Pelikan (1992) The Idea of the University: A Reexamination explored Cardinal Newman's conception of a university and the inherent value of what it teaches, something which forms the backdrop to Zero Tolerance. In B. Readings (1996) The University in Ruins, there was agreement with Emberley's view that the university has broken loose from its historical moorings. Readings (now deceased) believed that the university once existed to promote and protect national culture. However, the university now resembles a transnational corporation - focussed on operational goals which can be expressed in degrees of excellence and governance as a techno-bureaucracy with administration as the priority. On this point Readings was of a similar 
mind to Bercuson et al. But, unlike Emberley, Readings did not believe it would ever be possible to return to the historic mission of the university, principally because national cultures have withered away.

Reading's worry about the rising prominence of governance and administration has support. C. Hardy (1996) in The Politics of Collegiality has shown, by way of case studies of McGill, University of Montreal, University of British Columbia, Simon Fraser, University of Toronto and Carleton, the considerable extent to which universities have had to develop strategies and managerial techniques (read, a dramatically increasing administrative focus) to deal with financial retrenchment, shrinking enrolments and public demands for accountability. More horrifying still, for Emberley and the like-minded, S. Slaughter and L. Leslie (1997) in Academic Capitalism: Politics, Policies, and the Entrepreneurial University explained how governments in Canada, USA, UK and Australia view universities as vehicles to pursue national economic competitiveness. In compliance, universities are increasingly developing entrepreneurial skills and linking with business and government in the development of new academic programming and research. This is the very antithesis of Emberley's conception of a university.

Despite the many books in this decade lamenting the sorry state of higher education, I think Emberley's central thesis deserves a detailed examination. One reason is that his notion of the proper role of a university is likely to be very controversial. It will no doubt find support with many members of the professoriate, especially in the humanities and social sciences. However, for policy makers in provincial ministries of education, NSERC and SSHRC (who are promoting business/government/education partnerships in many of their grants), professional educators (e.g., law, business, social work, medicine, education and engineering), or professors who see themselves as being obligated to ready students for life in the new economy, Emberley's program will not be welcome news. In many respects, Professor Emberley stands against most of the current trends in higher education reform. I believe that his stylized picture of the university is flawed. It is very narrow, based on an impressionistic rendering of history and too reliant on history to justify the present. And, if policy decisions were to be driven by Emberley's vision, our troubled but basically sound universities would be significantly weakened. 
A second reason for wanting to focus on Zero Tolerance is that it provides a more comprehensive analysis than do most other works. Emberley sketches a rich conception of what a university should be and the type of the education that should take place within it. He considers the nature of the educational process, what knowledge should be taught and the central methods of teaching. His treatment of contemporary problems such as the politics of race and gender, and his various policy recommendations, flow from, and are justified by, his concept of a university education. Others, such as Pelikan (1992) and Readings (1996), dealt with the concept of a university but had less to offer on policy matters. D'Souza, Bercuson et al, Hardy and others addressed policy and administrative problems from the perspective of liberal education, but not based upon a full-fledged conceptual analysis of a university education. So, by providing a commentary on Emberley's position, the issues raised by others will be aired as well.

In what follows, I intend to set out and critique Professor Emberley's view of the university and its scholarly culture. I also want to consider his characterization of the two major agents of extremist reform - the corporate right and cultural left - since understanding their impact is important to appreciating his overall concept of education. Space limitations will restrict me to commenting on only one of his policy recommendations, namely his claim that universities should be detached from concerns about society and the economy and that applied and practical aspects of university programs should be separated into different institutions. It is essential to deal with this point because it is, likewise, central to his notion of a university. Emberley's views on tenure, tuition, distance learning technology and so on will need to wait for an evaluation by others.

\section{THE UNIVERSITY AND ITS SCHOLARLY CULTURE}

What is the function of a university? In answering this, Emberley follows very closely the work of the British idealist political philosopher Michael Oakeshott (1962a, 1962b, 1962c, 1967, 1972). To Emberley (and Oakeshott), the university cannot be understood properly outside of its historical context. So, Emberley begins his account with the founding of universities in the 13th century (pp. 26-29) and two counter-balancing conceptions of academe. The first is Universitas. This is an association 
bound together in common undertakings and by shared purposes. Its principle commitment is to the pursuit of knowledge and objective truth. He maintains that the roots of academe are evident in the ancient Socratic conception of developing political order and civil society through knowledge and the capacity for rational thought. With this is the desire to know morally right conduct as was exemplified by the life and teaching of Christ (pp. 30-33). The second conception of a university is civitas. An institution conceived of in this mode is not to be understood so much in terms of purposes, but of customs and the norms governing civil behavior. Essential is an atmosphere of civility which is conducive to conversation, discussion and debate. It requires a respect for the opinions of others and a willingness to probe, explore and understand them.

Emberley then blends universitas/civitas to give a characterization of the university in which the pursuit of knowledge and truth is engaged in by its members in an atmosphere of civilized intellectual exploration. This is the "scholarly culture" - a unique way of life that binds together professors and their students. A university education is, in effect, an initiation into this scholarly culture: it is a process of welcoming the younger generation into the genteel pursuits of academe.

An important feature of Emberley's account, following Oakeshott, is that education so construed does not have ends or objectives. It is a process. Emberley quotes Oakeshott, saying, "University education is not a beginning and not an end, but a middle ... a mysterious interaction of the needs of students and the scholarly culture"(pp. xii-xiii). Moreover, student needs are pitched in terms of intellectual, spiritual and emotional yearnings rather than, say, vocational skills or understandings. Emberley and Oakeshott are very much opposed to the idea that a university should be involved in professional education (e.g., business, law, engineering, medicine, etc.), or indeed, any specific preparation of students for the working world.

What are these processes of interaction? The answer is reading (pp. 39-48) and conversation (pp. 48-52). Books serve as the main way of awakening, cultivating and maturing students. They are an important vehicle for self-interpretation and the exploration of meaning. Conversation is a collaborative exchange: the creative interplay of judgements which involves qualifications, corrections, shifts in position, additions and refinements to points of view. As Emberley sums it up, 
"the forms of understanding and friendship that comprise the university's highest accomplishment emerge in the leisurely dialogues and meditative withdrawal that the university affords its members" (p. 257).

Emberley's exposition is wide ranging and its various pieces, elaborations and re-descriptions are peppered throughout the book. This makes it difficult to be sure that one has the complete picture, but the following seem to be the main points. His university is (1) a place where students are initiated into their cultural heritage. Education (2) is a process, not a means to further ends. (3) Reading and conversation are the main components of the process. (4) The role of a university is to deal with knowledge and moral understanding because they have inherent value, not social or economic utility. The university (5) should be substantially detached in its teaching and research from the direct day to day concerns of society. Students ought not to be specifically prepared for employment, nor should the university be a vehicle for economic or social development. (6) Certain commitments are essential to scholarship such as to the objectivity of knowledge and the pursuit of truth. (7) Civility knits the academic community together.

To appreciate the importance of these characteristics, and their place in the current public policy debates, it is very helpful to consider the two principal forces which Emberley thinks are driving the university away from its historic mission.

\section{THE CORPORATE RIGHT}

The corporate right, and its reformist agenda, is a "family-resemblance point of view that coalesces out of the opinions of rotarians and chambers of commerce, professional business organizations, recent governments on both left and right, the media, policy wonks at the Fraser Institute and the C.D. Howe Institute and many university managers" (pp. 153-154). Typical of this camp is a bottom-line orientation: it treats universities as the engines of economic growth, establishes performance measures based on economic efficiency and sees the university as an expense rather than an investment. The corporate right understands and addresses educational issues in the language of consumers and customers, marketing, privatization, re-engineering and rationalization. And among its hot buttons are greater representation of industry on university 
boards of governors, business/government/university partnerships and various user-pay approaches to financial issues such as vouchers and income contingent loan programs. Especially prominent on the corporate right's agenda is the demand for accountability, principally in the form of performance measures such as those provided by the Maclean's rankings (pp. 115-125).

Consider this in light of the first five characteristics identified a moment ago: (1) initiation, (2) process, (3) reading/conversation, (4) pursuit of what has inherent value, i.e., truth and goodness, and (5) detachment from economic and societal concerns. None of these items fits well with the corporate right's way of thinking. An initiation into culture is fine, to a point. But the business community wants graduates who can understand the world as it is, solve problems and employ fundamental business skills in dealing with day to day issues. Next, there may be many different processes undertaken to transmit knowledge and skill, but there must ultimately be a measurable result. The corporate right would never agree that education is solely a process. Further, reading and conversation are central to education. No one on the corporate right would likely deny this. But reading and conversation are not just educational processes, they are ends. Communication skills are essential to being effective in business. And, the corporate right would not be satisfied with a university education that dealt only with reading and conversation. It wants more by way of understanding and competency, namely, the kind of outcomes which other processes would lead to: internships in industry to develop competence in the business environment, technical skill development in computing and accounting, and so on. Concerning the pursuit of truth and goodness, the corporate right would not oppose this. But much more is demanded. There may be inherent value in the study of music and philosophy, but understanding the way the economy works has value too - practical, or instrumental, value. Finally, detachment would not be acceptable to business, government, research granting agencies and the general public. After all, they are calling for closer, not more distant, connections between academic institutions and the economy. 


\section{THE CULTURAL LEFT}

The opposing faction, the cultural left, is likewise committed to reforming universities. But, economic development and accountability are not the issues. The cultural left wants extensive social transformation. The university should be a change agent to bring about social equality in gender, race and ethnicity. Emberley's problem is that this goes well beyond social critique which is a commonly accepted function of universities. The cultural left has hijacked the mission of the university. Rather than teaching and learning as an exploration of the human experience through the arts, sciences and humanities, the cultural left has made the university and its educational activities into a social renovation project. Worse, its hostility is destroying the scholarly culture. Academe's characteristically civilized debate has yielded to the pressing of hot buttons related to gender and culture in a way that generates rage, abusive behavior and a climate of suspicion, animosity and litigiousness. The cultural left relies on vitriol, vindictiveness, sloganeering, hyperbole, obscurantism, humourlessness, vulgarity, taunts, abusiveness, cruel indecencies, belittlement and insensibility. He comments that the "cultural left's major contribution to the demise of Canada's universities is the pathologization of faculty and student behaviour, because in the empire of social work that the cultural left has built up at the university to 'cure' students and faculty, the first thing dispensed with was the natural trust inherent in the scholarly culture" (p. 202).

Whereas the corporate right violates the first five of the characteristics of Emberley's model university, the cultural left offends the remaining two. The university, qua universitas, requires an allegiance to (6) objectivity and truth. As civitas, its commitment is to (7), respectful conversation, openness and collegiality. But neither is possible with the cultural left which interprets all human interaction, thought and language as inherently political. So the ideals of objectivity and universal truth are rejected. Political action replaces argument, and its methods are not governed by the rules of civilized discourse. In consequence, Emberley maintains, "the cultural left's rhetoric and its eye to political gains have presented these changes in such a way as to produce paralysis and intolerance on Canada's campuses" (p. 212). 


\section{DETACHMENT AS A SOLUTION}

The university, as Emberley sees it, is pulled and pushed by the corporate right and cultural left in so many directions that it is unable to be effective in any of them. He says "the university cannot simultaneously be an engine of economic growth, a social welfare agency, a laboratory for new consciousness, a training center and a home for the scholarly culture. Something has to give" (p. 258). What he therefore proposes is the development of a system of higher education which would separate institutions whose grounding is in "theoretical" knowledge from those which deal with predominately "applied" knowledge. The former would be called universities and the latter, polytechnics. Emberley explains: "Universities would remain places where the culture of scholarship could proceed undisturbed and where the primary attention would be paid to frontier research, to cultivating critical reason and imagination and to fostering political citizenship and public service" (p. 262). ${ }^{1}$ By contrast, he says that the "polytechnics would house the research facilities associated with our 'engines of economic growth' and 'engines of social change' and with research in the fields of the applied sciences, thus serving the primary task of preparing students for vocations and fostering the pragmatic aspects of social reform" (p. 262).

This is a rather neat solution but is it a good one? I do not think it is. To show this we will consider, first, the strategy Emberley uses to make his case. Second, a closer look will be taken at the characteristics he thinks universities should have.

\section{IS EMBERLEY RIGHT ABOUT UNIVERSITIES?}

Many academics would agree that Emberley's university has a lot going for it. But to say that it has value is not to say that it is the only model which does. Some would prefer different approaches, even though they might admire the fine qualities of Emberley's. They might, for instance, believe that a two-tiered university system which differentiates research-based from teaching-based universities would more effectively achieve the objectives of both functions. Or, they might opt for a closer connection among universities, business and government as a better way of achieving broader societal objectives. But Emberley is not 
saying that his view is just one among several which are viable. He is convinced that his concept is the legitimate one. Others which are not compatible with his should be rejected.

Professor Emberley writes with intensity and passion. For the converted, there is much stirring encouragement. But anyone who has misgivings would find very little actual argument on the basis of which to come around the Emberley's way of thinking. Apart from his appeal to the reader to consider the needs of students and to see how his view accommodates this, he has a very limited range of persuasive strategies. There are, though, some arguments implicit in his program which we will explore.

\section{Oakeshott's Traditionalist Argument}

Emberley's description of the historical evolution of universities has a normative element. His presumption is that, except for the recent interruptions by the corporate right and cultural left, what has emerged from the historical process is what we should approve of today. Emberley does not use an independent set of educational criteria to evaluate the historical model. Instead, he uses the historically generated account as a criterion for analyzing contemporary situations and to project into the future what we ought to do. Granted, he does justify the specific content of his model by pointing to the inherent value of the knowledge with which the university should be concerned; and he shows how his approach addresses the ontological needs and yearnings of students. But he does not demonstrate why those educational aims and not others (i.e., preparing students for careers or developing research to help the economy) are preferable. He simply presumes an evolutionary result is sufficient accreditation for the present.

Emberley is vulnerable to the charge that no matter how appropriate his model might have been in the past, it is not what we need in our contemporary society. So, he requires an argument to legitimize his model. One possibility is to consider Michael Oakeshott's (1962a) treatment of this problem. While I do not want to impute to Emberley a view that he does not hold, this might be a way of grounding the historical rendering in a supportive theory. Since he does adopt both Oakeshott's concept of education and methodology of historical exegesis, the argument would be compatible with Professor Emberley's overall position. 
Like other idealist philosophers, such as Burke, Hegel and Bradley, Michael Oakeshott believed that social institutions cannot be understood independently from their intellectual and institutional traditions. We are conceptually locked into our past. It is our traditions which enable us to generate new ideas about what we can do with our political and social institutions in the future. We build upon what we know. Our future concepts are only extensions of what we already have. Based on our direct and indirect experiences of the past and our understanding of our cultural traditions, we are able to advance in the future by making adjustments to our existing institutions. Oakeshott referred to this as the "pursuit of intimations" (1962a, p. 133). In deciding what to do, we should use our judgement about what will enhance the very best aspects of our traditions. Implicitly, we evolve our institutions for the better. So, in Oakeshott's view, the normative elements of change are embedded in the historical development (Benn \& Peters, 1959). Universities today, therefore, can only be extensions of their historical development and this evolutionary form is superior to all others.

Let us assume that Oakeshott's "traditionalist theory" is correct. In order for it to support Emberley's model, the model itself needs to be an accurate reflection of the historical evolution. I am not sure that it passes this test. For instance, Emberley portrays the university of the past as being devoted to theory and truth. But, many Canadian and American universities were founded in the 19th century more to serve religious interests than scholarship and independent thought (Careless, 1953/1991, p. 162; Ladd \& Lipsett, 1975, p. 11; Lipsett, 1993). Ladd Jr. and Lipset (1975) maintained about American colleges that "faculty did not stray far from traditional revealed truth. Professors sought to socialize new generations in the accepted system of values. Colleges were largely centers of conventional thought"(p. 11). And as for the supposition that universities have, historically, been detached from concerns about society, the economy and careers, this is not really accurate either. As Whitehead (1929, 1967) observed 70 years ago,

At no time have universities been restricted to pure abstract learning. The University of Salerno in Italy, the earliest of European universities, was devoted to medicine. In England, at Cambridge, in the year 1316, a college was founded for the 
special purpose of providing 'clerks for the King's service.' Universities have trained clergy, medical men, lawyers, engineers. Business is now a highly intellectualized vocation, so it fits well into the series. (p. 92)

In the past century, universities have been used to prepare young people for the needs of the economy. Niblett (1974) observed, "the pressure grows on higher education in almost every country to produce graduates useful to a society eager for more and more technology and know-how. This pressure can be seen to have been growing for at least a hundred years" (p. 2). And, as Bliss (1987) noted about recent Canadian history, "In the late fifties, higher education of all kinds was sold to Canadians as the only way to develop the nation's 'human capital"' (p. 500 ). He went on to point to the explosion of interest in business education throughout the 1960's. In fact, according to the Canadian Federation of Business School Deans (1994), from 1970 to 1990, the number of Canadian university degrees in all disciplines doubled. During the same period, business education flourished and degrees increased by a factor of roughly 4.5 times. Moreover, concerning the US experience, Jencks and Reisman (1968) contended that, "purity of motive and single-mindedness of purpose have never been characteristic of American colleges . .. the question has always been how an institution mixed the academic with the vocational, not whether it did so" (p. 199). So, if Emberley is saying that the university of today should mirror the scholarly culture of the past, it seems reasonable to question how much of his account is representative of historical realities and how much is idealized. ${ }^{2}$ Granted, Emberley may be correct and those cited above wrong. But, at very least we can say that Emberley's sketch of the past is controversial.

To press the traditionalist strategy further, we could ask that if history does justify the future, could history legitimate a different future than Professor Emberley's? Suppose we looked back thirty years to a time in universities that predates the turmoil caused by the corporate right and cultural left. Would we encounter then, the kind of institution which Emberley recommends? I do not think that we would.

For over a century, one prevalent university model in North America has been the "multiversity", 3 namely a many-purposed institution which includes, graduate schools, research institutes, joint ventures with business, professional education as well as the arts, humanities, social and 
natural sciences. This model has been developing consistently since the turn of the century (Kerr, 1963; Rothman, 1993, p. 41). In the US, as the land grant institutions were founded during the 19th century, engineering, agriculture, home economics and business were brought into the university. Even Harvard, Columbia, Chicago and many other private institutions, grew well beyond the liberal arts. There was more of a liberal arts tradition in Canada until the end of World War II. But since that time the American model seems to characterize virtually all of the major provincial universities (e.g., UBC, Alberta, Saskatchewan, Manitoba, etc.) as well as McMaster, Toronto, Queen's, McGill, Dalhousie and so on. So if the past gives justification for the present, as traditionalists maintain, does not the multiversity concept have as much of a claim to legitimate standing as the historical notion which Emberley has explicated?

Even if we allowed that Emberley's liberal arts conception is the correct historical product, it is very difficult to see why we should accept the normative position that it should be adopted today. Oakeshott is right to say that we cannot completely escape our intellectual past. We cannot stand apart from the conceptual structure embodied in our language an historical product. But we can work within its framework to construct new realities for ourselves. Even if we inherit the image of a liberal arts college, we can amend it to focus, say, more on research than on student centered-teaching. Or we can alter a discipline-based curricula and the resulting "inert knowledge", as Whitehead (1929/1967) used to say, and change to the problem solving orientation favored by Dewey (1938/1973). We do not need to wipe clean our conceptual make-up in order to envision something new and suitable to our needs. We can formulate educational principles on the basis of which to make a normative assessment of the desirability of retaining unaltered the institutions which are the legacy of history. Oakeshott is right to say that we are influenced by the past. We are not imprisoned by it, though.

\section{The Essential Characteristics of Universities}

Let us try another approach to examining Emberley's model by delinking it from history and focusing on the conditions he thinks describe a proper university. Start with those which the corporate right seems to offend: (1) initiation, (2) process, not ends, (3) reading/ 
conversation, (4) truth and goodness as inherently valuable, (5) detachment: education as non-vocational.

When we say that education is an initiation into a cultural heritage, items (2), (3) and (4) explain what is entailed by that. Speaking of education as a process is very important because it tells us that the enterprise is never complete. And this is germane to Emberley's view. If he is correct, the emphasis placed by the corporate right on accountability and performance measures is inappropriate because there should never be an end to evaluate. But, surely this cannot be correct. Even if we agree that a person's education is never finished because there is always more room for him or her to develop and to learn, it is still possible to refer to someone as being an "educated person". At some point we can claim that the university's institutional job is done. As Peters (1967) says, "'being educated' is the achievement relative to a family of tasks which we call processes of education" (p. 2). In universities, students pass courses and are granted degrees. Institutional processes come to an end. The corporate right's desire for performance targets and accountability relates to the achievement aspect of the concept of education. The real issue is not questioning whether universities should have ends, targets or goals, it is establishing those which are most appropriate.

Much the same could be said about reading/conversation as educational processes. No one associated with universities would deny their worth. But other processes have value too. Experimentation in science, field trips in archeology, performance in music, internships in government for political science students, co-op placements for engineers and business students, etc. are process examples that, while they are in no way incompatible with reading/conversation, are not extensions of them. Emberley is so focused on reading/conversation that his university appears to be dedicated mainly to the humanities. He certainly does not rule out the sciences, but it is hard to see how a student who concentrates on physics and math, where the central processes are experimentation, analysis, calculation, testing, evidence and proof, would fit into his notion of what a university should be doing.

Where Emberley's program has some strong potential support is in characteristic (4): universities should be engaged in activities which have inherent value. As a justification for the detachment of universities from concerns of the economy, jobs and so forth ((5) above), this view is 
similarly prominent in the writing of Matthew Arnold (1886/1932), Cardinal Newman, 1858/1925), Allan Bloom (1987) and certainly Oakeshott (1962a, 1962b). Because Emberley also takes the view that students should be educated for citizenship, his conception has similarities to that of the ancient Greeks. While he may not subscribe to their metaphysical realism, namely that through knowledge the mind attains its own end i.e., knowing the essential nature of things and grasping what is ultimately real and immutable, he would share with Plato the commitment to the pursuit of knowledge for its own sake - its inherent value. But, is this an adequate justification for moving the applied studies out of the university in a remodeling of the Canadian university sector?

Grant that learning for its own sake is desirable. Does this mean, thereby, that other reasons for learning do not have value? Does the recognition that learning has inherent value exclude the legitimacy of learning something because it has instrumental value (Griffiths, 1965)? Why should instrumental justifications be rejected out of hand? To begin with, it is important to distinguish between two types of instrumental justification: those which are external to the activity in question and those which are internal (Peters, 1973,1977). First, suppose we said that the justification for studying biology is that it leads to happiness. We would be giving a reason for doing it that is not part of biology. Happiness per se is not dependent upon anything to do with biology. And taking courses in biology may not lead to happiness. Happiness and biology are not part of each other. Happiness is external to biology and may be used as an instrumental justification only if in fact it does result from studying biology.

Now consider an instrumental justification which is internal to the subject of study. Having the ability to earn a living as a biologist or to gain entry to medical school requires the prior study of biology. In these cases biology is not being studied for its own sake, but as a means to a further end. But the ends in question are connected to biology; they are attained specifically by studying the discipline. The justification is instrumental, but internal to what is being studied.

Instrumental justifications of the first kind, are not the real competition for Emberley because they may work in some circumstances and not others. They are only contingently related to the subject of study. The second type of instrumental justification cannot be so easily dismissed. 
Suppose the argument is made that taking a BA in English literature prepares a student well for a career in the public or private sectors because of the qualities and capacities it develops: sensitivity to other people, communication skills, the capacity to comprehend difficult written positions and the ability to see through complex arguments and prepare reasoned responses. This internal instrumental justification is embedded in the study of literature. So, why is this not an acceptable reason for studying this discipline? Or, what if a student began taking a major in literature because of a love for the subject but later came to see its practical value and pursued it because the prospect of a job as a magazine editor overtook inherent value as the main attraction? In this case the inherent value justification gave way to the instrumental value. Indeed, the reverse could be the case. If a student began an engineering program with a career in mind, then became fascinated by the subject matter and continued for that reason, the justification would have been instrumental first, then intrinsic. The reality for most students is that what piques their interest at one time, differs from that at another. Finally, some subjects such as business, medical or environmental ethics combine what has value in its own right with prescriptions for improving the way institutions in the public and private sectors behave which is valuable for their outcomes. Inherent and instrumental values are interwoven. In sum, I can see no reason why either justification, alone or in combination is not adequate.

Professor Emberley's point (5) is that a university should be detached from the concerns of the economy and the career preparation of students. This is hard to justify. Universities, produce "public goods" as well as the benefits to students that we have been talking about. Many in the educational debate are demanding a greater contribution from universities to the capacity of the country to compete in the international economic order (Slaugher \& Leslie, 1997). Why then could this not be legitimately considered? The benefits to industry and national competitiveness are directly connected to the teaching and research mandates of the university, so the justification may be instrumental but it is an internal part of what universities do. The notion of instrumental value supports inclusion, not exclusion.

Keeping theory and its application together in the university has advantages. As I have argued elsewhere (Carson, 1998), central to the 
notion of a liberal education from Plato onwards has been a fundamental concern with the whole person - emotions, intellect and spirit. It involves guiding students toward clarity and truth; developing in them an appreciation of the principles that are at the foundation of human knowledge; and helping them to acquire the scholarly virtues, such as respect for evidence, open-mindedness and tolerance for the views of others. There is nothing about the so-called applied subjects that is inconsistent with this. Engineering students study fluid mechanics; in education there is cognitive psychology and in business, students take courses in finance. In all respects that are relevant to liberal education, these courses do not differ from those in the arts, humanities, social sciences or natural sciences. Indeed, in most cases, the professional courses are applications or derivations of them. Further, professional and applied programs would be badly harmed if they were forced out of universities. An undergraduate business education, for example, usually requires that thirty to fifty percent of the course work be done in arts and sciences. Essential to a professional education in any field is exposure to a wide variety of disciplines and perspectives. This would be lost if business and other applied programs were conducted outside of the university environment.

\section{Objectivity and Civility in the University}

To be sure, there have always been debates within the university about the nature of objectivity and truth (6). But the cultural left is importing something very different. Searle (1995, p. 28) comments, "there has been a sea change in discussions of the aims of education in that the ideals which were previously shared by nearly everyone in the disputes - ideals of truth, rationality and objectivity, for example - are now rejected by many of the challengers even as ideals. This is new." For the cultural left, the transformation of society is the ideal. It is maintained that all texts, ideas, opinions and statements are cultural. They are expressions of power by dominant groups, i.e., white males of European decent. This viewpoint rests on the notion that we cannot know anything absolutely. All knowledge is relative. A perspective can only be judged within the context of an interpretive framework, for example, by the norms of a particular group or culture (Martin, 1993, pp. 207-211). 
The main problem with this transformational thesis, and Emberley recognizes it (p. 107), is that these epistemological underpinnings are highly dubious (Martin, 1993; Searle, 1995). Unfortunately for the theory of relativism, the relativists themselves are its biggest liability. They claim we are trapped within our cultural belief-system. We are in a conceptual box and are unable to see outside or grasp higher order principles that would allow us to evaluate the validity of norms, beliefs and judgments within our own box or those of another belief-system. But, the relativists, themselves, seem to have managed to escape. If they were trapped like everyone else they would see only the confines of their own box. Indeed, they would not be able to grasp the notion that they were confined or that there would be something beyond confinement. The relativists invariably seem to be able to draw on principles and understandings that go beyond the interior of their own boxes which they then use to evaluate themselves and others. The cultural left, for example, appears to know that political principles like equality and liberty for women and minorities ought to have a higher priority than other principles, such as research or preparation for employment, in establishing what universities should do. So they have been able to discover knowledge and truth beyond their own box. And they have been able to judge their own principles to be superior to the principles of the box in which their political opponents conceptually reside. Relativism it seems does not even appear to have the support of its own proponents. Now, the fact that relativists do not act in accordance with their own theoretical commitments does not mean that relativism as a theory is wrong. But it does mean that the political actions of the cultural left do not have a grounding in a theory that they actually believe.

Very few philosophers or social scientists would deny that subjectivity plays a considerable role in the way that we perceive situations, approach problems and evaluate evidence. We all make judgments based on personal values and perspectives - everyone is subjective to some extent. But, the cultural left seems to leverage the admission of some subjectivity all the way to cultural revolution. That is far too extreme. Characteristic of actual scholarly research is an ongoing attempt to make adjustments and corrections which are necessary to manage the results of importing one's own point of view into the investigation (Passmore, 1984, p. 158). All that is being claimed is that there is an objective reality that is external to the investigator and that it has at least some important 
function in determining what is true and how adequate a theory is in explaining the world (Martin, 1993, p. 213).

Emberley knows that the attack on objectivity by the cultural left, mainly through postmodernist theory, will not bring an end to the university (p. 113). But I am less worried about its pervasiveness or harmful effects than he is. The postmodernists put their politics forward in a way that closes off the possibility of any reasoned debate just as does Marxist dogma or even existentialist ideology, both of which were prevalent in the 1960s. Despite the fact that Marxists and existentialists would at least admit the possibility of objective truth, neither would accept as legitimate any evidence that could be used to refute their theories. Critiques of Marxism were dismissed as nothing more than the political moves of the dominant social classes against the oppressed. And existentialists deflected challenges with the claim that they were inauthentic. We hear much less from them today. Postmodernism will, similarly, find its place in our intellectual history as new academic paradigms take over.

Moving, finally, to Emberley's condition of civility (7), there are two issues to examine: the relationship between university and civility, and the extent of the damage being done by the uncivilized behavior of the cultural left. On the first matter, we need to establish whether the concept of a university is really inextricably wound up with the notion of civility. Consider three possibilities. First, civility is a central part of the concept of university - i.e., the relationship between them is one of logical necessity. Since Emberley defines a university in terms of civitas and conversation (an inherently civilized form of discourse) he is committed to this strong form of link between civility and the university. Accordingly, an institution which does not embody the characteristic of civility as Emberley describes it could not be called a university. Second, the concept of a university logically implies a weaker version of civility - the minimum enabling conditions of discourse. Individuals must at least allow others to speak and be heard. Third, we could say that civility is a quality indicator of a university. Institutions in which courtesy, decorum, graciousness, politeness, etc. are typical characteristics are qualitatively superior to those in which we find only the minimal conditions of discourse enablement.

Emberley is committed to the first interpretation. He gets the second interpretation for free since his richer notion of civility implies minimum 
enabling conditions. And, he subscribes to the third, not only because it is his preference, but because the evaluative approval of civility is packed into his conceptual analysis of academe in the first interpretation.

If Emberley had argued from the standpoint of the third interpretation, i.e., that civility is merely a quality indicator, he would have found this difficult to sustain. He could claim that universities are better places if they are civilized; the cultural left could counter that civility may be desirable, but it is not as important as raising the awareness of members of the academic community to issues of justice and equality in relation to race and gender. The issue of which position should take priority would doubtless end in a standoff. It is unlikely that the parties would be able to agree on a higher order principle on the basis of which the dispute could be resolved. This is mainly because the cultural left would not admit to any universal principles beyond politics. The second interpretation, (i.e., minimum enabling conditions) would probably have been acceptable to the combatants. Even the cultural left would concede that everyone has a right to be heard, notwithstanding that their ultimate objectives are more political than epistemological. Their theoretical position does not compel them to be completely belligerent.

This would not have been enough for Emberley, though. It is unfortunate because in terms of logical necessity, this is all that is implied by the concept of a university. Even if we accept Emberley's description of the hostile environment that exists within Canadian universities and the civility which has been its casualty, we still call these institutions universities, and their graduates continue to be regarded as being educated. Whatever conclusions we might draw about quality, the concept of university is still intact despite the lack of civility. And, as for the essential link between universities and conversation, suppose a university operated entirely by a non-interactive distance technology or by correspondence. Students and faculty would certainly communicate with one another, and learning would take place. Some academics might argue that this is a very poor substitute for face-to-face interchanges, but the institution could still be said to be a university and the students educated by it. The same point could be made in the case of students sitting in large classes where lectures are given and questions asked and answered, but with little Emberley-style conversation taking place. In these situations the issue of civility does not really come to the forefront. In sum, it 
is hard to escape the conclusion that Professor Emberley has drawn us a picture of one type of a university - not the full spectrum of qualifiers.

The second issue to be considered is the extent of damage being done by the cultural left. This is hard to assess. But, I think there is much less of it than Emberley does. Not all members of the cultural left are militant; or if so, not as boorish as he describes. Further, some institutions across Canada are more socially conservative than others: In them, the enmity and rancor is considerably less. Finally, the postmodernist debate is more localized within universities than Emberley represents. The hard sciences and professional schools hear much less about it. Academe may suffer, but will survive.

\section{CONCLUSION}

It is easy to see great value in Professor Emberley's conception of a student-centered institution which connects the scholarly culture with the ontological yearnings of students and seeks to meet their needs through reading and leisurely conversation in subject areas which are of inherent value. But this would not necessarily meet everyone's needs. University subjects can have instrumental as well as inherent value, and many students are attracted to the former as well as the latter. That is why applied degree programs such as engineering and business are so popular with undergraduate students. And, it is at least part of the reason why parents, business, government and the public are willing to support universities. I doubt that anyone would oppose the humanistic model; they would not, however, want to be constrained to support it alone.

The weakness in Zero Tolerance: Hot Button Politics in Canada's Universities is that it does not provide a very good answer to someone who wants to know why only a single alternative is legitimate. Cambridge, Oxford, Edinburgh, London, Paris and Harvard do not fit the model put forward by Emberley, but they are clearly among the greatest universities in the world. Surely there are arguments to support them. What I think contributes to their enduring status is the very fact that they are engaged so broadly across the forms of human knowledge and activity. They combine the theoretical and the applied; and they are capable of fulfilling the needs of their highly diverse educational constituencies. The vast majority of Canadian universities do this well, and it is a 
tremendous strength, in my judgement. Whereas Emberley fears that the stress of dealing with multiple demands is crippling universities, I think that developing a capacity to respond to these many-sided pressures is what generates their ability to deal with a complex future.

\section{References}

Arnold, M. (1886/1932). Culture and anarchy. Cambridge, UK: Cambridge University Press.

Arthur, J., \& Shapiro, A. (Eds.). (1995). Campus wars: Multiculturalism and the politics of difference. Boulder, CO: Westview Press.

Benn, S., \& Peters, R.S. (1959). Social principles and the democratic state. London: George Allen \& Unwin.

Bercuson, D., Bothwell, R., \& Granatstein, J.L. (1997). Petrified campus: The crisis in Canada's universities. Toronto, $\mathrm{ON}$ : Random House.

Bliss, M. (1987). Northern enterprise: Five centuries of Canadian business. Toronto, ON: McClelland \& Stewart.

Bloom, A. (1987). The closing of the American mind. New York, NY: Touchstone. Careless, J.M.S. (1970/1991). Canada: A story of challenge. Toronto, ON: Stoddart.

Carson, A.S. (1998). What are the university's obligations in the new economy? In L. Groarke (Ed.) The ethics of the new economy (pp. 9-23). Waterloo, ON: Wilfrid Laurier University Press.

Dewey, J. (1938/1973). Experience and education. New York, NY: Collier Books.

Dickman, H. (Ed.). (1993). The imperiled academy. New Brunswick, NJ: Transaction Publishers.

D'Souza, D. (1992). Illiberal education: The politics of race and sex on campus. New York, NY: Vintage.

Emberley, P.C. (1996). Zero tolerance: Hot button politics in Canada's universities. Toronto, ON: Penguin.

Fact book. (1994). Ottawa, ON: Canadian Federation of Business School Deans.

Griffiths, A.P. (1965). A deduction of universities. In R.D. Archambault (ed.) Philosophical analysis and education (pp. 187-207). London, UK: Routledge \& Kegan Paul.

Jencks, C., \& Reisman, D. (1968). The academic revolution. New York, NY: Doubleday.

Kerr, C. (1963). The uses of the university. Cambridge, MA: Harvard University Press. 
Ladd, E.C., Jr., \& Lipset, S.M. (1975). The divided academy: Professors and politics. New York, NY: McGraw-Hill.

Lipset, S.M. (1993). The sources of political correctness on American campuses. In H. Dickman (Ed.), The imperiled academy (pp. 71-96). New Brunswick, NJ: Transaction.

Martin, J.L. (1993). The university as agent of social transformation: The postmodern argument considered. In H. Dickman (Ed.) The imperiled academy (pp. 203-238). New Brunswick, NJ: Transaction.

Menand, L. (Ed.). (1996). The future of academic freedom. Chicago, IL: University of Chicago Press.

Newman, J.H. (1858/1925). The idea of a university defined and illustrated. London: Longmans, Green \& Co.

Niblett, W.R. (1974) Universities between two worlds. London, UK: University of London Press.

Oakeshott, M. (1962a), Political education. In M. Oakeshott, Rationalism in politics and other essays (pp. 1-36). London, UK: Methuen.

Oakeshott, M. (1962b). The study of 'politics' in a university. In M. Oakeshott, Rationalism in politics and other essays (pp. 301-333). London, UK: Methuen.

Oakeshott, M. (1962c). The voice of poetry in the conversation of mankind. In M. Oakeshott, Rationalism in politics and other essays (pp. 197-247). London, UK: Methuen.

Oakeshott, M. (1967). Learning and teaching. In R.S. Peters (Ed.), The concept of education (pp. 156-176). London, UK: Routledge \& Kegan Paul.

Oakeshott, M. (1972). Education: The engagement and its frustration. In R.F. Dearden, P.H. Hirst, \& R.S. Peters (Eds.), Education and the development of reason (pp. 19-49). London, UK: Routledge \& Kegan Paul.

Passmore, J. (1974). The objectivity of history. In P. Gardiner (Ed.), The philosophy of history (pp. 145-160). Oxford, UK: Oxford University Press.

Pelikan, J. (1992). The idea of the university: A reexamination. New Haven, CT: Yale University Press.

Peters, R. S. (1967). What is an educational process? In R.S. Peters (Ed.), The concept of education (pp. 1-23). London, UK: Routledge \& Kegan Paul.

Peters, R.S. (1973). The justification of education. In R.S. Peters (Ed.), The philosophy of education (pp. 239-267). Oxford, UK: Oxford University Press.

Peters, R.S. (1977). The meaning of quality in education. In R.S. Peters (Ed.), Education and the education of teachers (pp. 22-45). London, UK: Routledge \& Kegan Paul. 
Readings, B. (1997). The university in ruins. Cambridge, MA: Harvard University Press.

Rothman, S. (1993). Tradition and change: The university under stress. In H. Dickman (Ed.), The imperiled academy (pp. 27-70). New Brunswick, NJ: Transaction.

Searle, J.R. (1995) Postmodernism and the western rationalist tradition. In J. Arthur, \& A. Shapiro (Eds.), Campus wars: Multi-culturalism and the politics of difference (pp. 28-48). Boulder, CO: Westview.

Slaughter, S., \& Leslie, L. (1997). Academic capitalism: Politics, policies, and the entrepreneurial university. Baltimore, MD: The Johns Hopkins University Press.

\section{Notes}

1 Since citizenship and public service are tied to the way government and the economy actually function, it is hard to imagine how this objective could be achieved if the university considered only theory not application. Also, the "theory" and "applied" distinction is very artificial. For example, the discipline of finance is a central to all business school programs, but its theory is highly mathematical and based on proofs. It can be applied of course. But so can most scientific and social scientific theory. Organizational behaviour, to take another example, is applied psychology.

2 I make a similar point in Carson (1998).

3 This famous term was coined by Clarke Kerr (1963).

4 Perhaps one might argue that we should be looking at the far distant past - the Middle Ages. But if so, it makes that historical or 'traditionalist' argument look trumped up: tradition is defined as whatever time line supports the preferred position. 